\title{
KESADARAN DAN TANGGUNGJAWAB PELESTARIAN LINGKUNGAN MASYARAKAT MUSLIM RAWA PENING KABUPATEN SEMARANG
}

\author{
Benny Ridwan \\ Mahasiswa Program Doktor UIN Sunan Kalijaga Yogyakarta \\ bennyridwan@stainsalatiga.ac.id
}

\begin{abstract}
This study aims to determine the role of the preservation of the environment and the consciousness and social solidarity in the Rawa Pening Muslim community. The data was collected through observation and interviews with informants around Rawa Pening. In analyzing the data this research applying the Culture Theme Analisis and interpretive methods. The role of the Muslim community for the preservation of the environment seen through the activities "resik-resik rowo"(pond cleaning), do not throw plastic waste, do not use electric shock and poisons in fishing, changing litter into useful things, regularly breed the fish and do "sedekah rowo" (pond charity). the solidarity formed through the "ronda" or the night watch by turns, compassion and belping others, changing conflict into a peace, promoting bonesty, and prioritize prayer time.
\end{abstract}

Keywords: Muslim Community, Rawa Pening, Environment Preservation

\begin{abstract}
Abstaks
Penelitian ini bertujuan mengetahui peran masyarakat Muslim terhadap pelestarian lingkungan serta mengkaji kesadaran dan solidaritas sosial masyarakat Muslim di Rawa Pening. Pengumpulan data dilakukan melalui observasi serta wawancara dengan informan berada di sekitar Rawa Pening. Dalam menganalisis data menggunakan metode analisis tema kultural dan interpretif. Peran masyarakat Muslim untukpelestarian lingkungan terlihat melalui perilaku "resik-resik rowo", tidak membuang sampah plastik, tidak menggunakan strum dan racun dalam mencari ikan, merubab sampab jadi berkah, selalu menebarkan benih ikan dan melakukan "sedekab rowo". sementara solidaritas terbentuk melalui jaga malam secara bergantian, belas kasib dan membantu orang lain, merubah konflik menjadi apik, mengedepankan kejujuran, dan mengutamakan waktu sholat.
\end{abstract}

Kata Kunci: Masyarakat Muslim, Rawa Pening, Penyelamatan Lingkungan 


\section{Pendahuluan}

Krisis lingkungan sudah sampai kepada tahapan yang mengancam eksistensi bumi sebagai tempat tinggal manusia dan makhluk lain. Krisis yang terjadi saat ini bersumber pada kesalahan fundamental-filosofis dalam cara pandang manusia terhadap dirinya, alam, dan keseluruhan ekosistem. Sebagai akibatnya, kesalahan pola perilaku manusia terutama dalam berhubungan dengan alam. Upaya untuk penyelamatan lingkungan telah banyak dilakukan mulai dari penyadaran kepada masyarakat (stakeholders), upaya pembuatan peraturan, kesepakatan nasional dan internasional, undang-undang sampai kepada penegakan hukum, tidak terkecuali penyelamatanpun dilakukan melalui pemanfaatan sains dan teknologi serta program-program teknis lain. Semua bentuk upaya tersebut ternyata belum dapat menahan laju kerusakan lingkungan yang semakin parah. Sehingga diperlukan pendekatan alternatif lain dalam penanganannya, yaitu melalui pendekatan etika lingkungan yang berbasis kepada nilai-nilai keislaman. Pendekatan ini menjadi penting untuk landasan moral bagi semua aktivitas manusia yang berkaitan dengan lingkungannya dan penekanannya pada asas keseimbangan dan kesatuan yang tidak hanya terbatas pada dimensi fisik dan duniawi tetapi juga dikaitkan dengan dimensi spiritual terutama dengan konsep (teologi) penciptaan alam. Jadi, terdapat hubungan antara alam sebagai suatu realitas dan realitas yang lain yakni Yang Menciptakan Alam.

Krisis lingkungan yang terjadi di sekitar Rawa Pening layak menjadi bahan untuk dikaji secara akademis. Rawa Pening adalah sebuah rawa di Kabupaten Semarang, Jawa Tengah. Luasnya 2.670 hektare. Hampir seluruh permukaan rawa ini tertutup tanaman Eceng Godok. Tanaman sejenis gulma ini menutupi Sungai Tuntang, terutama di bagian hulunya. Akibatnya, berdampak terjadinya elevasi (penyusutan) air rawa yang kemudian menyebabkan gagal panennya petani di sekitar areal rawa. Meskipun telah dilakukan upaya pembuangan empat kubik per detik per hari dalam seminggu namun ketinggian permukaan Rawa Pening tetap di atas normal. Upaya tersebut sebenarnya dilakukan untuk menurunkan ketinggian permukaan air Rawa Pening akan tetapi ratusan hektar sawah tetap mengalami gagal panen. Kenaikan elevasi itu antara lain disebabkan 
karena intensitas hujan yang sangat tinggi yang diakibatkan curah hujan yang tinggi. Elevasi permukaan Rawa Pening menjadi naik dan menggenangi ratusan hektar sawah siap panen.

Rawa Pening juga sebagai salah satu objek wisata kondisinya kian parah akibat penurunan daya tampung. Penelitian dari Pusat Studi dan Pengembangan Kawasan Rawa Pening (PSPKRP) Universitas Kristen Satya Wacana Salatiga tahun 2007 (Wardani, dkk, 2007:1-10), menunjukkan kondisi ini disebabkan sedimentasi dari sembilan subdaerah aliran sungai yang bermuara di Rawa Pening ataupun endapan Eceng Godok yang sudah mati. Eceng Godok dalam bulan Juni tahun 2008, dengan pola sebaran yang tidak terlalu rapat, bisa menutupi sekitar 70 persen Rawa Pening. Bahkan, Dinas Lingkungan Hidup, Pertambangan, dan Energi (LHPE) Kabupaten Semarang menyebut tutupannya bisa mencapai 82 persen dan menyerap 5,6 juta meter kubik air per tahun (Lee, 2008).

Menurut Ketua PSPKRP UKSW Naniek Sulistya Wardani, pada tahun 1976 kedalaman maksimal Rawa Pening sekitar 14 meter, tetapi saat ini kurang dari 4 meter. Sebagian mata air alami juga tertutupi sedimentasi yang berkisar 780 ton hingga 1.189 ton per tahun (Wardani, dkk, 2007: 10-13). Dengan kondisi ini, genangan air memang bisa menjadi sangat merusak pertanian warga. Dinas Pertanian dan Perkebunan Kabupaten Semarang menyebutkan, tiga tahun terakhir luasan sawah masyarakat yang terkena luapan air terus meningkat. Pada tahun 2006 tercatat sekitar 56 hektar, naik menjadi 113 hektar pada tahun 2007, dan hingga pertengahan April 2008, sawah tergenang melonjak tajam jadi 542 hektar dengan lahan puso 285 hektar. Penurunan kemampuan daya tampung waduk alami ini bila terus dibiarkan akan membuat areal persawahan warga yang tergenang semakin bertambah.

Berdasarkan latar belakang yang telah diuraikan di atas, maka peneliti bermaksud untuk mencari jawaban atas persoalan peran masyarakat Muslim Sekitar Rawa Pening terhadap usaha pelestarian lingkungan di Rawa Pening, dan faktor-faktor apa yang mempengaruhi peran masyarakat tersebut. Serta realitas kesadaran dan solidaritas sosial masyarakat Muslim sekitar Rawa Pening, menjadi penting untuk pelestarian lingkungan. 


\section{Diskursus Lingkungan dan Etika Pelestarian}

Penelitian yang muncul seputar etika lingkungan hidup diantaranya adalah Tesis Muhirdan, yang berbicara tentang etika lingkungan hidup dalam Alquran. Dalam tesis yang berbasis penelitian literatur dan tafsir itu disebutkan bahwa pengungkapan terma-terma lingkungan hidup sangat jelas diungkapkan oleh Alquran. Etika lingkungan hidup sangat urgen untuk diterapkan, dan akumulasi kerusakan lingkungan hidup sudah semakin meningkat (Muhirdan, 2008: 2).

Sementara itu buku yang diangkat dari disertasi karya $\mathrm{Mu}-$ jiono Abdillah; Agama Ramah Lingkungan Perspektif Alquran terbitan Paramadina secara lugas membahas seputar asal usul teologi lingkungan dan secara konsepsi Islam lebih luas ketimbang konsep agama-agama lain mengenai lingkungan hidup (Abdillah, 2001:3). Disertasi Mudhofir juga tidak jauh berbeda; Argumen Konservasi Lingkungan sebagai Tujuan Tertinggi Syari'ah, yang diperkuat juga dalam tulisannya di jurnal Ijtihad; Globalisasi dan Krisis Ekologi: Upaya Konservasi Dalam Perspektif Fikih Lingkungan, menyebutkan bahwa konservasi adalah amanah bagi semua makhluk hidup untuk memelihara aneka ragam kehidupan dengan segenap sistemnya. Konservasi yang dilakukan melalui pelestarian, perlindungan, pemanfaatan secara lestari, rehabilitasi, dan peningkatan mutu lingkungan untuk menjamin kemaslahatan manusia beserta makhluk hidupdalam keberlanjutannya. Dengan demikian tanpa lingkungan yang baik kehidupan manusia menjadi tidak berarti. Argumen ini menegaskan bahwa konservasi lingkungan menjadi tujuan tertinggi syariah (Mudhofir, 2009: 1-7). Disamping itu juga disertasi Rahmat berjudul Implementasi Nilai-nilai Islam Terhadap Pembinaan Kesadaran Lingkungan Hidup di MAN Daerah Istimewa Yogyakarta, mengulas tentang hubungan antara materi pelajaran Akhlak dengan kesadaran lingkungan para siswa (Rahmat, 2007: 4).

Buku Menggagas Figh Sosial, dari Soal Lingkungan Hidup, Asuransi, Hingga Ukhuwah karya Ali Yafie menyoroti soal lingkungan hidup dalam perspektif fiqh. Meizar Said \& Aziz Ghufron, Etika Lingkungan dalam Perspektif Yusuf Qardawi, Al Jami'ab Vol 44 No 1 tahun 2006 lebih membicarakan issu lingkungan dalam 
perspektif kajian hadits serta tulisan Emil Salim tentang Islam dan Lingkungan Hidup, Al Jami'ah no 241980 berbicara hubungan Islam dan Lingkungan Hidup.

Penelitian yang dilakukan oleh Naniek Sulistya Wardani, dkk tahun 2007 tentang pentingnya pelestarian lingkungan di sekitar wilayah Rawa Pening berada dalam lingkup sosial ekonomi. Sementara itu penelitian yang dilakukan oleh Balai Pengkajian Teknologi Pertanian (BPTP) Jawa Tengah tahun 2001 juga pada kisaran sosial ekonomi (BPTP Jawa Tengah, Laporan penelitian, 2001).

Buku karya A. Sonny Keraf tentang Etika Lingkungan (2006) dan buku karya Mary Evelyn Tucker \& John A Grim tentang Agama, Filsafat, dan Lingkungan Hidup (2007) juga dijadikan role model dalam penelitian ini. Buku itu secara sistematis menjelaskan tentang persoalan etika, teori etika lingkungan, politik lingkungan, Iptek dan lingkungan serta kearifan tradisional dalam ikut serta menyelamatkan lingkungan. Walaupun semua penelitian di atas bersifat kajian literatur tafsir, hadits, fiqh, teologi, filsafat (kecuali penelitian BPTP dan Nanik Wardani, dkk) maka penelitian ini berposisi menjadi penelitian lapangan dan mencoba untuk memberikan pemahaman pentingnya arti kesadaran, tanggung jawab, solidaritas dan etika lingkungan sebagai dasar keberhasilan masyarakat dalam mengupayakan usaha bersama untuk mendayagunakan sumber daya lingkungan, memelihara lingkungan, serta meningkatkan daya dukung lingkungan secara berkelanjutan demi kelangsungan dan kesejahteraan hidup masyarakat itu sendiri.

Dalam penelitian ini dibangun berdasarkan 3 teori. Pertama adalah teori etika lingkungan ekosentrisme. yang memusatkan etika pada semua komunitas ekologis baik yang hidup dan benda-benda abiotis lainnya saling terkait satu dan lainnya (Keraf, 2006: 33-76). Teori ini akan digunakan untuk melihat usaha pemulihan kembali keseimbangan ekosistem yang telah rusak oleh tindakan manusia. Alam boleh dimanfaatkan, tetapi harus dengan bijaksana. Segala sumber daya alam hendaknya dimanfaatkan dengan bijaksana guna menciptakan kesejahteraan optimal bagi sebanyak mungkin orang dan dalam kurun waktu yang selama mungkin pula. Maka, pengelolaan lingkungan serta sumber daya alam harus ditangani oleh 
negara demi kemakmuran bersama warga negara. Dan negara pun harus memahami dan menjiwai benar etika alam. Sehingga, alam pun tidak dirusak oleh negara yang tentu saja memiliki kekuasaan, wewenang dan otoritas yang tinggi.

Kedua adalah teori yang dibangun seorang sosiolog yang memberi perhatian cukup intens terhadap masalah agama, Emile Durkheim, melihat pentingnya peran konteks dalam melahirkan etika moralitas komunitas, antara lain mengatakan bahwa karena individu dalam suatu konteks tertentu, hidup di tempat yang sama dan berhubungan dengan obyek atau alam yang relatif sama, maka tiap individu kemudian akan memiliki pengalaman yang relatif sama. Hal ini kemudian melahirkan nilai, emosi, kepercayaan dan sentimen yang juga relatif sama. Artinya, situasi dan kondisi sosial masyarakat menentukan bentuk pemahaman orang terhadap agamanya (Durkheim, 1955: 10-15 bandingkan dengan Durkheim, 1965: 62).

Teori ketiga dibangun oleh Othman Llewelyn (2007) yang menyebutkan bahwa Islam merupakan agama (jalan hidup) yang sangat memperhatikan lingkungan dan keberlanjutan kehidupan di dunia. Banyak ayat Alquran dan hadits yang menjelaskan, menganjurkan bahkan mewajibkan setiap manusia untuk menjaga kelangsungan kehidupannya dan kehidupan makhluk lain di bumi. Konsep yang berkaitan dengan penyelamatan dan konservasi lingkungan (alam) menyatu tak terpisahkan dengan konsep keesaan Allah (taubid), syariah, dan akhlak. Sungguh, akan sangat efektif jika warta keagamaan bisa menjadi entry point bagi penyelamatan dan konservasi lingkungan hidup. Pada pendapat lain, agama adalah sumber nilai-nilai etika yang tak pernah kering, karena agama melihat hakikatnya manusia pada perbuatan baiknya (Asy'arie, 2001: 126).

Teori ini juga menjadi penting mengingat agama dipandang mampu menjadi rem yang ampuh bagi hasrat manusia untuk melakukan suatu hal yang bersifat merusak. Memang, tidak selamanya agama mampu memerankan perannya yang semacam itu. Namun, ketika jalur sains, atau jalur-jalur lainnya terhambat, 'pintu agama' bisa menjadi salah satu pintu untuk masuk ke dalam jiwa 
setiap orang, yang pada akhirnya mempengaruhinya agar tidak merusak lingkungan.

\section{Metode Penelitian}

Merujuk pendapat Amin Abdullah, jika studi agama ingin tetap ilmiah dan memperoleh integritas intelektualitasnya dan juga untuk menjernihkan bercampuraduknya dimensi doktrinal-teologisnormatif dan kultural-historis diperlukan refleksi kritis yang biasa diwakili oleh pendekatan kritis-filosofis. Pada batas-batas tertentu pendekatan fenomenologi juga perlu dipertimbangkan. Diharapkan pendekatan fundamental-filosofis dapat menyumbangkan jasa baiknya dalam menjernihkan dan menengahi keruwetan dan ketercampuradukan antara dimensi doktrinal-teologis dan dimensi kultural-historis (Abdullah, 2000: 8).

Pengumpulan data lapangan diperoleh pada lokasi penelitian yang meliputi wilayah 6 desa pada 4 kecamatan: kecamatan Ambarawa, Bawen, Tuntang, dan Banyubiru. Keenam desa tersebut adalah Desa Asinan, Banyubiru, Kebondowo, Kesongo, Lopait, dan Desa Tuntang.

Pengumpulan data dilakukan dengan observasi dan dokumentasi ke lokasi penelitian serta wawancara dengan informan atau keyperson terpilih. Pengumpulan data primer dilakukan dengan informan (a) bermata pencaharian pertanian rawa, nelayan rawa, pengrajin Eceng Godok, Aparatur desa. Penetapan lokasi ini ditentukan setelah melakukan studi penjajagan (exploratory research) serta melalui wawancara mendalam dengan informan terpilih serta instansi yang terkait.

Teknik pemilihan informan yang peneliti gunakan adalah melalui snowball sampling. Teknik pemilihan informan ini juga berdasarkan latar belakang social, pendidikan, ekonomi serta tingkat pemahaman dan pengalaman keagamaan mereka. Informan juga berasal dari informan ahli yang dianggap mengerti dengan situasi, isu dan problem wilayah penelitian, (Salganik and Heckathorn, 2004:193-239). Selanjutnya data yang terkumpul kemudian dipahami melalui penalaran induktif sampai akhirnya dianalisis. 


\section{Bentuk kegiatan penelitian}

Penelitian dilakukan dalam bentuk keliling go for walk a round artinya peneliti (bersama beberapa key person) sekaligus melakukan tugas keliling dari desa ke desa (on site visit) untuk melaksanakan tugas penelitian (mobil unit). Hal itu dilakukan dengan pertimbangan agar pelaksanaan penelitian dan peningkatan integrasi sosial dan pemberdayaan dapat dilakukan sesuai dengan setting masyarakat desa.

\section{Analisis data}

Data yang telah diklasifikasikan kemudian dianalisis dengan menggunakan metode Analisis Tema Kultural dan metode Interpretatif. Analisis Tema Kultural (Spradley, 1980:140) adalah analisis dengan memahami gejala-gejala yang khas. Analisis ini mencoba mengumpulkan sekian banyak tema, fokus budaya, nilai, dan simbol-simbol budaya yang ada dalam setiap domain. Selain itu, analisis ini berusaha menemukan hubungan-hubungan yang terdapat pada domain yang dianalisis, sehingga akan membentuk satu kesatuan yang holistik, yang akhirnya menampakkan tema yang dominan dan mana yang kurang dominan. Pada tahap ini yang dilakukan oleh peneliti adalah: (1) membaca secara cermat keseluruhan catatan penting, (2) memberikan kode pada topiktopik penting, (3) menyusun tipologi, (4) membaca pustaka yang terkait dengan masalah dan konteks penelitian. Berdasarkan seluruh analisis, peneliti melakukan rekonstruksi dalam bentuk deskripsi, narasi dan argumentasi. Analisis ini memerlukan kepekaan, kecerdasan, kejelian, untuk bisa menarik kesimpulan secara umum sesuai sasaran penelitian.

Sementara metode lnterpretasi menjadi penting manakala digunakan untuk memahami hakikat persoalan. Sesungguhnya interpretasi merupakan upaya yang sangat penting untuk menyingkap kebenaran (Kaelan, 2005: 76-77). Interpretasi bukan merupakan kegiatan yang tidak bertanggungjawab melainkan kegiatan yang bertumpu pada evidensi obyektif dan akan mencapai kebenaran obyektif. Data yang menjadi basis penelitian ini kemudian diinterpretasikan sesuai dengan kebutuhan zamannya. 
Penafsiran dan pemahaman (Cox, 2006: 235) suatu fenomena religius meliputi empati terhadap pengalaman, pemikiran, emosi, ide-ide dari orang lain dsb. Tindakan memahami ini tidak akan diperoleh lewat pengalaman reproduktif dari emosi dan pemikiran orang lain. Mengalami dengan cara imitatif atau reproduktif bukan merupakan kondisi untuk memahami pengalaman orang lain. Untuk itu dianjurkan mempergunakan hermeneutik, sebab hermeneutik adalah dasar Geisteswissenschaften (ilmu sosial kemanusiaan).

\section{Analisis}

\section{Sekitar Regulasi Lingkungan}

Masyarakat yang tinggal di sekitar Rawa Pening umumnya tergolong dalam strata ekonomi menengah dan menengah bawah. Hal ini terlihat dari bangunan-bangunan rumah yang semi permanen dengan menggunakan genteng dari tanah liat dan sebagian masih memasak menggunakan minyak tanah atau kayu bakar, serta sumber air masih diambil secara manual dari dalam sumur. Indikator lain terlihat dari penggunaan transportasi yang digunakan yaitu angkutan umum dan untuk beberapa Rumah Tangga (RT) sudah memiliki sepeda motor. Mata pencaharian utama masyarakat di sekitar Rawa Pening utamanya sebagai petani sawah, nelayan tambak dan tangkap, petani Eceng Godok, pengambil gambut untuk pupuk, berdagang dan jasa wisata air, serta sebagai perantau di luar kabupatan Semarang.

Secara umum, telah banyak regulasi yang mengatur pengelolaan kawasan Rawa Pening. Namun dalam pelaksanaanya, partisipasi stakeholders Rawa Pening (pemerintah, masyarakat, LSM, pengusaha, dan pihak terkait lainnya) belum memberikan hasil yang memuaskan. Belum optimalnya peran pemerintah juga diakui oleh Ahmad Asma'i, "dari dulu sampai sekarang yang saya ketahui peran dari pemerintah sendiri belum optimal mas. Untuk pelestarian lingkungan rawa walaupun ada tapi belum semua", (wawancara dengan Ahmad As'ami, 36 tahun). Pada sisi lain Harun Al Rosyid menyebutkan bahwa "Masyarakat mau bergerak kalau ada dana dari pemerintah baru dibersihkan jika tidak, maka tidak ada" (wawancara dengan Harun Al Rosyid, 56 tahun). Sementara 
itu menurut Bagus Jinggo, menyebutkan bahwa "Peran pemerintah adalah melakukan pembersihan dan penebaran bibit dan biasanya dilaksanakan dalam 1 tahun sekali". (wawancara dengan Bagus Jinggo, 32 tahun) Berdasarkan dari situasi itulah beberapa anggota masyarakat berinisiatif membentuk solidaritas dalam menghadapi dampak lingkungan.

Pada sisi lain kondisi Rawa Pening yang saat ini mengkhawatirkan karena terjadi masalah ekologi dan problem fisik rawa sendiri seperti sedimentasi. Sedimentasi merupakan konsekuensi dari perairan yang bersifat lentik. Sedimentasi tersebut tentu saja dapat mengancam keseimbangan ekologis di Rawa Pening. Sedimentasi yang terjadi dapat disebabkan oleh dua sumber, yakni sumber allochtonous dan autochtonous. Sumber allochtonous meliputi materi-materi yang terbawa sungai-sungai yang bermuara di Rawa Pening, erosi dari hulu, serta kegiatan penduduk di sekitarnya. Sumber autochtonous yaitu berasal dari perairan itu sendiri seperti pembusukan gulma air dalam hal ini Eceng Godok dan alga yang mati. Sedimentasi terjadi akibat akumulasi perlakuan masyarakat pada daerah tangkapan dan erosi pada tebing serta gejala agregasi muara sungai yang terjadi serta adanya pembuangan limbah diluar kendali oleh masyarakat di sekitar Rawa Pening.

Di samping minimnya peran pemerintah dalam pelestarian lingkungan Rawa, permasalahan ekologi dan sedimentasi, masyarakat yang menggantungkan hidupnya pada ekosistem Rawa Pening juga menghadapi persoalan pencemaran limbah hotel dan restaurant. Pencemaran limbah hotel dari Kabupaten Semarang yang masuk ke aliran sungai menuju Rawa Pening cukup mengkhawatirkan. Hal tersebut merupakan imbas dari buruknya pengelolaan limbah di masing-masing hotel, dan restoran. Terutama pada hotel dan restoran yang belum memiliki instalasi pengolahan air limbah (IPAL). Menurut Kepala Badan Lingkungan Hidup (BLH) Kab. Semarang, Supramono, "Kami mencatat ada pencemaran di Rawapening. Pencemaran tersebut semakin parah setelah masing-masing hotel dan restoran tidak memiliki IPAL, sehingga limbah yang ada langsung masuk ke aliran sungai dan bermuara di Rawapening." Pencemaran ini juga berakibat pada minimnya kawasan tangkapan ikan. Perairan yang dapat dihuni oleh ikan 
menjadi semakin sedikit, dan akhirnya kawasan tersebut menjadi rebutan para nelayan. A. Adro'i menyebutkan bahwa, "para nelayan mengalami kesusahan untuk mencari ikan dan nyarinya jadi muter".

\section{Masyarakat Muslim Rawa Pening dan Problematika Lingkungan}

Di samping masalah sedimentasi dan pembuangan limbah, sejak dulu hingga sekarang, perkembangan Eceng Godok (Eichornia crassipes) di Rawa Pening, Kabupaten Semarang, juga sulit untuk bisa diatasi. Akibatnya, perkembangbiakannya yang makin meluas mengganggu aktivitas nelayan rawa di wilayah Kecamatan Tuntang, Bawen, Ambarawa, dan Banyubiru Kabupaten Semarang. Akibatnya, warga yang menggantungkan hidupnya dari Rawa Pening, termasuk ribuan petani dan nelayan dari empat kecamatan di wilayah Kabupaten Semarang pun merasakan kesulitan dari tahun ke tahun. Pengakuan Kasiyan selaku Ketua Kelompok Nelayan Upoyo Wino dan Ketua Kelompok Tani Nelayan Andalan Desa Tuntang, bahwa; "Sekarang, untuk memperoleh ikan sekilo per hari sulitnya bukan main. Hal itu disebabkan mulai sesaknya lahan untuk mencari ikan," (wawancara dengan Kasiyan, 42 tahun).

Kesesakan ini terjadi akibat makin banyaknya jumlah nelayan di sekitar Rawa Pening yang mencari ikan atau mendirikan kerambakeramba ikan. Mereka yang mencari ikan di danau tersebut, memang tak hanya nelayan di sekitar Rawa Pening, akan tetapi juga nelayan luar. Mereka sama-sama menggantungkan hidupnya pada Rawa Pening. Akibatnya, terjadilah persaingan dalam mencari ikan, sehingga rawan konflik. Konflik pernah terjadi pada tahun 2006 antara warga pada satu pihak dengan pemerintah, satpol PP dan Satgas Rawa Pening yang berasal dari warga sipil. Konflik ini terjadi akibat razia penggunaan alat tangkap ikan branjang klambu yang sebenarnya sudah dilarang. (www.suaramerdeka.com/berita 10 Maret 2006, diakses 29 Juli 2012). Pelarangan itu bertujuan agar pelestarian ikan di Rawa Pening tetap terpelihara. Meski Pemerintah Kabupaten (Pemkab) Semarang telah menerbitkan aturan tentang pembagian zona penangkapan ikan melalui Perda Nomor 25 Tahun 2001 tentang Pengelolaan Budi Daya Ikan di Rawa Pening (sebagai perbaruan Perda Nomor 16 Tahun 1999), fakta di lapangan ternyata masih menunjukkan banyaknya nelayan yang melanggar batas zona 
yang ditentukan.

Pertumbuhan Eceng Godok yang relatif cepat membuat para nelayan kesulitan untuk menuju ke tengah rawa untuk menangkap ikan, untuk itu menurut A.Adro'i, resik-resik rowo sangat berguna untuk memberikan akses jalan tadi. Hasil resik rowo ini juga dimanfaatkan bagi pengerajin Eceng Godok. Bahkan menjunjung kebersamaan sebagai bentuk solidaritas yang terwujud juga dalam bentuk jaga malam di lingkungan rawa. Jaga malam ini diberlakukan karena aktivitas ekonomi warga juga dilakukan malam hari. Jaga malam juga dilakukan dengan gentenan atau gentian (bergantian). Selain itu juga aktivitas warga di Rawa Pening sangat mempertimbangkan hari, "kalau hari jum'at warga libur, dan kalau sore berangkat setelah maghrib karena yang lebih diutamakan waktu sholat. Ungkapan kalau hari jum'at warga libur, dan kalau sore berangkat setelah maghrib karena yang lebih diutamakan waktu sholat". (wawancara dengan A. Adro'i)

Sementara itu Bagus Jinggo juga menyadari bahwa masyarakat memiliki pandangan bahwa agama berpesan untuk menjaga lingkungan (Wawancara dengan Bagus Jinggo, 32 tahun). Pada perspektif lain Badri menyebutkan bahwa "Yang maha kuasa menciptakan alam semesta buat umatnya. Saya hanya menjalankan apa yang diperintahkan oleh yang maha kuasa" (Wawancara dengan Badri, 60 tahun). Masyarakat Muslim Rawa Pening menyadari bahwa alam semesta termasuk dunia seisinya ini adalah sebuah realitas empirik yang tidak berdiri sendiri, akan tetapi berhubungan dengan realitas yang lain yang non-empirik dan transenden. Setiap sesuatu di alam semesta ini adalah pertanda akan eksistensi Yang Ghaib. Artinya masyarakat Muslim Rawa Pening menyadari bahwa aktifitas lingkungan menyatu dan tak terpisahkan dengan ketauhidan mereka.

Pada perspektif lain Badri menyebutkan bahwa Yang Maha Kuasa menciptakan alam semesta bagi umatnya. Saya hanya menjalankan apa yang diperintahkan oleh yang Maha Kuasa”. Dalam konteks ini apa yang mereka lakukan merupakan beyond particular theological object yang oleh Amin Abdullah disebutkan bahwa ketika manusia membidik, mencermati, memahami, dan menajami 
hal-hal yang "ada di belakang" (beyond particular theological object), maka diskursus seperti itu memasuki wilayah yang lebih bersifat transcendental-spiritual. Rasa pasrah yang tanpa syarat kepada Sang Pencipta, panggilan berbuat baik kepada sesama makhluk, pengakuan adanya yang "suci", rasa ketergantungan kepada yang "maha” segalanya, permohonan dan doa untuk memperoleh bimbingan jalan yang selamat dan begitu seterusnya adalah termasuk wilayah yang disebut-sebut sebagai wilayah yang bersifat fundamental spiritual-filosofis. Hal-hal fundamental-filosofis yang bersifat transhistoris dan transteologis adalah dimensi ontologis dari agama-agama, termasuk di dalamnya adalah agama Islam. Amin Abdullah menyebutkan bahwa dimensi 'ontologism', sebenarnya, menunjukkan adanya makna yang sangat mendalam, mendasar, transendental dan sekaligus spiritual. Nilai-nilai spiritualitas seperti itu tidak hanya dimiliki oleh budaya dan agama tertentu, tetapi dimiliki oleh berbagai tradisi dan agama yang dimiliki oleh umat manusia. Hal demikian paralel saja dari apa yang disebut oleh al-Qur'an secara explicit bahwa setiap kelompok budaya punya jalan sendirisendiri yang ia pilih. (al-Maidah, 48). Oleh karenanya, setiap agama berbeda-beda dalam menjabarkan, menafsirkan, membahasakan, mengaktualisasikan dimensi spiritualitas-transendentalitas ini lantaran faktor bahasa dan budaya yang selalu menyertai dimensi ontologism ini. Namun demikian, orang beragama yang matang dan otentik, tidak perlu harus segera terjebak pada faktor historisitas budaya dan bahasa (cultural determinism), lantaran di samping dimensi historisitas budaya dan bahasa yang sangat manusiawi tersebut, masih ada dimensi transendentalitas-spiritualitas yang juga sangat manusiawi. (Abdullah, 2006:229-231). Dalam perspektif itu, agama dipahami dan dihayati oleh masyarakat sebagai sebuah cara hidup, dengan tujuan untuk menata seluruh hidup manusia dalam relasi yang harmonis dengan sesama manusia dan alam. Dalam penghayatan agama seperti itu, masyarakat selalu ingin mencari dan membangun harmoni di antara manusia, alam, masyarakat, dan dunia gaib, dengan didasarkan pada pemahaman dan keyakinan bahwa yang spiritual menyatu dengan yang material. Harmoni dan keseimbangan sekaligus juga dipahami sebagai prinsip atau nilai paling penting dalam tatanan kosmis. Pada sisi lain Penulis juga 
menyetujui teori yang dibangun oleh Durkheim bahwa definisi agama menurutnya adalah suatu "sistem kepercayaan dan praktek yang telah dipersatukan yang berkaitan dengan hal-hal yang kudus, kepercayaan-kepercayaan dan praktek-praktek yang bersatu menjadi suatu komunitas moral yang tunggal." Dari definisi ini ada dua unsur yang penting, yang menjadi syarat sesuatu dapat disebut agama, yaitu "sifat kudus" dari agama dan "praktek-praktek ritual" dari agama. Agama tidak harus melibatkan adanya konsep mengenai suatu mahluk supranatural, tetapi agama tidak dapat melepaskan kedua unsur di atas, karena ia akan menjadi bukan agama lagi, ketika salah satu unsur tersebut terlepas. Di sini dapat dilihat bahwa sesuatu itu disebut agama bukan dilihat dari substansi isinya tetapi dari bentuknya, yang melibatkan dua ciri tadi. Durkheim juga menyebutkan bahwa agama selalu memiliki hubungan dengan masyarakatnya, dan memiliki sifat yang historis. Pengaruh langsungnya adalah setiap perilaku manusia, bahkan sikap batin yang paling tersembunyi di lubuk hati, harus ditempatkan dalam konteks yang sacral, dalam spiritualitas. Maka, baik secara individual maupun kelompok, perilaku dan sikap batin manusia harus murni, bersih, baik terhadap diri sendiri, sesama manusia, maupun terhadap alam. Sikap hormat dan menjaga hubungan baik, yang tidak boleh dirusak dengan perilaku yang merugikan, menjadi prinsip moral yang selalu dipatuhi dan dijaga dengan berbagai ritus dan upacara religious-tradisional. Lebih lanjut dari itu keterlibatan pemimpin agama menjadi penting adanya.

Kutut Suwondo (Dekan Fisipol UKSW Salatiga, www. suaramerdeka.com/Rawa Pening, diakses 29 Juli 2012) mengatakan, permasalahan sosial ekonomi yang muncul di seputar Rawa Pening terjadi ketika daya dukung tidak mampu lagi menjadi penyangga tuntutan penduduk, pengusaha, dan tuntutan pembangunan yang terus meningkat. Dari catatan Paguyuban Tani Nelayan Sedyo Rukun pada 1999, ada 1.503 tani nelayan yang mencari dan membudidayakan ikan di danau tersebut.

Kutut Suwondo menyebutkan, bahwa pada 2002, perkembangan nelayan dan pekerja lain melonjak dua kali lipatnya atau menjadi sekitar 3.000 orang. Apabila tiap anggota keluarga nelayan dan pekerja lain ada tiga orang, maka paling tidak terdapat 9.000 
orang yang menggantungkan hidupnya pada Rawa Pening. Mereka berasal dari sepuluh desa, yakni Desa Asinan, Bejalen, Banyubiru, Kebondowo, Rowoboni, Rowosari, Sraten, Kesongo, Lopait, dan Desa Tuntang. Kesepuluh desa itu tersebar di empat kecamatan yakni Kecamatan Banyubiru, Bawen, Ambarawa, dan Kecamatan Tuntang, Kabupaten Semarang.

Ketua Forum Rembuk Rawa Pening, Wibowo, 36 tahun mengatakan, ba wamasalah penangkapan ikan oleh nelayan memang terjadi sejak lama. Sebelum tahun 1991, sebenarnya masyarakat sekitar Rawa Pening memiliki rasa kepemilikan yang besar terhadap Rawa Pening. Namun setelah diterbitkan Perda Nomor 16 Tahun 1999 tentang Pengelolaan Sumber Daya Ikan di Rawa Pening, ternyata hampir $70 \%$ pengguna alat tangkap ikan tidak diperbolehkan.

Mereka yang tadinya dilarang, merasa bersalah mengambil sikap mendiamkan saudara-saudaranya yang mengambil ikan dengan alat tangkap racun dan setrum. Pemakaian alat yang merusak lingkungan ini terjadi hingga tahun 1999. Akibatnya, penyalahgunaan kedua alat tangkap itu sempat merajarela beberapa saat. Akibat masyarakat tidak memperdulikan penyalahgunaan alat tangkap setrum dan racun itu, pendapatan ekonomi masyarakat turun drastis. Bila biasanya pendapatan nelayan dalam mencari ikan rata-rata mencapai Rp 15 ribu/hari, dengan merajalelanya penggunaan racun dan setrum, turun menjadi Rp 5 ribu/hari. Di lain pihak, penghasilan mereka yang memakai alat tangkap racun dan setrum mencapai Rp 50 ribu/hari.

Selain berdampak terhadap ekologi dan kehidupan ekonomi, persoalan Rawa Pening juga berpotensi menimbulkan konflik internal masyarakat yang memiliki kepentingan berbeda. Keberadaan Eceng Godok menjadi salah satu persoalan yang krusial, di satu sisi mengakibatkan kerugian sistem pertanian, akan tetapi oleh sebagaian masyarakat, ternyata Eceng Godok merupakan sumber mata pencaharian, karena dapat digunakan untuk berbagai macam bentuk kerajinan, souvenir, hiasan dan perlengkapan rumah tangga lainnya. Konflik antara petani rawa, nelayan dan pengerajin Eceng Godok ini juga diperparah akibat perbedaan dalam partisipasi aktif, solidaritas, rasa saling percaya, toleransi, terjalinnya suatu jaringan 
sosial dan asosiasi yang fungsional untuk kerjasama kolektif yang berkelanjutan untuk pelestarian lingkungan.

\section{Upaya Masyarakat Muslim Rawa Pening menjaga Eksistensi Lingkungannya}

Untuk mengatasi hal tersebut di atas, masyarakat Muslim Rawa Pening yang berada di desa Banyu Biru memiliki cara bagus dalam mengelola Eceng Godok yang dulunya merupakan sampah bagi masyarakat nelayan rawa karena menggangu aktifitas mereka dalam mencari ikan. Masyarakat Muslim disini lebih memilih mengelola Eceng Godok menjadi bahan dasar kerajinan anyaman setelah melalui proses pengeringan. Disamping itu masyarakat mengolah hasil endapan/sedimentasi Eceng Godok yang mati di perairan rawa menjadi pupuk kompos yang bernilai ekonomi tinggi. "Kami mengolah sampah Eceng Godok ini menjadi bahan dasar anyaman untuk berbagai macam kerajinan tangan, kerajinan mebel dan furniture serta lainnya, sementara endapan Eceng Godok yang mati dapat dijadikan pupuk kompos" (wawancara dengan Jumadi).

Eceng Godok, kalau dibiarkan begitu saja, bakal menjadi masalah terutama di musim hujan ataupun pada masa tanam padi. Pertumbuhan gulma ini dengan cepat dapat menutupi permukaan air rawa. Hasil kajian pemerintah, perguruan tinggi dan dukungan partisipasi masyarakat mulai melakukan tindakan merubah sampah Eceng Godok menjadi berkah bagi siapapun yang mau memanfaatkannya. Dalam beberapa tahun terakhir, kegiatan resik-resik rowo banyak digelar di sejumlah desa di pinggiran rawa. Pada kegiatan itu juga masyarakat dibantu pemerintah menabur benih-benih ikan. Kegiatan ini jelas merupakan sesuatu yang sangat baik, dalam rangka menciptakan rawa yang bersih. Dalam kegiatan tersebut, lingkungan rawa dibersihkan dari Eceng Godok yang tumbuh secara sporadis, karena pada dasarnya Eceng Godok juga berguna bagi tempat berkembang biaknya ikan-ikan rawa. Kemudian Eceng Godok dikumpulkan dan diantar ke tempat pengepul sementara, lalu diteruskan ke tempat pengolahan. Pada hari-hari biasa Eceng Godok ini juga diambil oleh nelayan atau petani tradisional, kemudian dikumpulkan dan diantar ke tempat pengepul sementara, lalu diteruskan ke tempat pengolahan. 
Petani rawa, nalayan, pengerajin, hingga pengepul dituntut jujur dalam transaksi mereka. Pembagian hasil panen, pembagian dan distribusi pupuk, rentan terhadap praktik ketidakjujuran. Sikap-sikap kejujuran juga harus dimiliki para pengrajin dan pengepul saat transaksi jual beli Eceng Godok dalam keadaan kering dan basah.

Eceng Godok merupakan serat alam yang ramah lingkungan sehingga aman untuk bahan kerajinan dan menjadi trend bisnis kedepan. Aneka kerajinan dari bahan Eceng Godok bisa kita dapatkan di berbagai toko kerajinan atau supermarket. Peluang usaha kerajinan Eceng Godok semakin menemukan tempatnya, seiring dengan pengembangan kerja sama industri kerajinan dan mebel berbasis bahan baku Eceng Godok antara Indonesia dengan Pemerintah Mesir. Dengan kerjasama ini diharapkan mampu memberi manfaat bagi pelaku Usaha Kecil dan Menengah (UKM) di kedua belah pihak. Selain itu dalam kerjasama ini Indonesia di dukung oleh Kamar Dagang dan Industri Indonesia (Kadin) serta Asosiasi Industri Permebelan dan Kerajinan Indonesia (Asmindo). Dengan dukungan dari dua lembaga tersebut diharapkan posisi tawar Pengrajin Kerajinan Eceng Godok yang termasuk dalam Usaha Kecil Dan Menengah (UKM) lebih kuat (http://galeriukm.web. $\mathrm{id} /$ unit-usaha/handicraft/bisnis-kerajinan-eceng-gondok, diakses tanggal 3 September 2012).

Pengembangan bisnis kerajinan Eceng Godok selain ditujukan untuk peningkatan kesejahteraan masyarakat terutama kelompok Bisnis Usaha Kecil Dan Menengah (UKM) juga bermanfaat dalam mendukung lingkungan hidup daerah sekitar. Sebab, tanaman Eceng Godok selama ini masih dianggap sebagai tanaman yang merugikan, karena dapat menyebabkan terjadinya pendangkalan perairan, penyumbatan irigasi, penyebab terjadinya banjir, dan tempat bersarangnya nyamuk. Salah satu toko display yang menjual produk akhir dari anyaman Eceng Godok ini dapat kita jumpai di depan objek wisata Rawa Permai di jalan Salatiga Semarang. Toko ini mencoba memanfaatkan potensi alam yang melimpah tersebut di desa-desa pinggir rawa. Di samping itu juga masyarakat Muslim dipinggir rawa tidak hanya dilatih mengolah Eceng Godok namun juga dilatih bagaimana melakukan pengawasan terhadap mutu dan mampu mengetahui trend yang disukai pasar. Dengan cara 
ini diharapkan mereka akan menjadi pengrajin yang professional. Pelatihan pengawasan mutu ini melibatkan Dinas Perindustrian setempat.

Seorang pengrajin kerajinan Eceng Godok Warsinah, yang tinggal di Kesongo, menyebutkan bahwa ia telah menggeluti bisnis kreatif mengubah tanaman Eceng Godok menjadi kerajinan bernilai ekonomi tinggi. Kerajinan dari bahan dasar Eceng Godok buatannya lain berupa hiasan dinding, sandal, taplak meja, bantal kursi dan dompet. Jika sudah berbentuk barang kerajinan ini, kesan Eceng Godok sebagai tanaman yang tadinya tak bernilai pun menjadi sirna. Awalnya Warsinah bisa membuat kerajinan dari Eceng Godok itu belajar orang, setelah itu dia belajar dan mencoba mandiri, sementara produknya sendiri diekspor ke luar negeri antara lain Amerika, Australia, Inggris dan terakhir Arab Saudi. (Wawancara dengan Warsinah, 40 tahun)

Lain lagi dengan Bagus Jinggo yang mengatakan bahwa banyak warga disini menekuni bisnis kerajinan Eceng Godok dalam skala usaha kecil dan Rumah tangga. Meski demikian ketekunan warga dalam menganyam Eceng Godok dan menghasilkan berbagai bentuk kerajinan mampu menghantar produknya ke pasar Amerika Serikat, Belgia dan Australia. Jika berbagai solusi itu bisa dilakukan, maka sampah Eceng Godok bukan lagi sesuatu hal yang bermasalah, tetapi justru mengandung berkah yang bisa menjadikan rupiah. (Wawancara dengan Bagus Jinggo, 32 tahun)

Kehidupan sosiokultural masyarakat Muslim Rawa Pening yang tinggal di daerah pinggiran rawa ini mempunyai pola prilaku menjunjung kebersamaan. Rasa kebersamaan masyarakat yang berada di pinggiran rawa diwujudkan dalam bentuk kerja bakti, gotong royong, gugur gunung, sambatan, jagongan dan rewang. Apabila ada tetangga punya hajat seperti supitan (khitan), babaran (melahirkan), mantenan (pesta perkawinan), layat (takziyah) tanpa diundang pun tetangga yang lain bersedia dan siap membantu. Rasa kebersamaan ini juga terwujud dalam bentuk resik-resik rowo. Resik rowo ini dilakukan sebagai pola kebersamaan, karena sama-sama tinggal dan hidup disekitar rawa. Sama-sama menjadikan rawa sebagai sumber mata pencaharian ekonomi, sama-sama sebagai 
pemilik tanggung jawab. Tindakan resik rowo ini dilakukan secara bersama-sama sebagai bentuk kesadaran dalam melestarikan lingkungan rawa sebagai sumber mata pencaharian masyarakatnya. Resik rowo ini dilakukan untuk membersihkan rawa dari meluasnya pertumbuhan gulma (Eceng Godok). Banyaknya jumlah nelayan di sekitar Rawa Pening dan pendirian keramba-keramba ikan, menciptakan persaingan dalam mencari ikan, sehingga rawan konflik. Konflik juga terjadi akibat razia penggunaan alat tangkap ikan branjang klambu, setrum dan racun yang sebenarnya sudah dilarang. Namun karena masyarakat memiliki kesadaran, solidaritas serta tanggung jawab terhadap lingkungan, maka konflik tadi berubah menjadi apik/baik.

Pada sisi lain tradisi yang masih dilaksanakan oleh masyarakat sekitar Danau Rawa Pening adalah Sedekah Rowoyang dilaksanakan setiap tahun pada bulan Suro atau bulan Muharram menurut kalender tahun Hijriyah. Seperti yang dijelaskan oleh Khamim, 42 Tahun bahwa ia pernah ikut acara sedekahan itu pada tahun 1992. Hal ini senada dengan apa yang diakui oleh Harun Al Rosyid bahwa ia pernah ikut tapi ia lupa apakah acara tersebut masih berlangsung atau sudah macet. Bagus Jinggo memperkuat apa yang dialami oleh Khamim dan Al Rosyid, maupun Badri, yang menyebutkan bahwa kalau bulan suro warga pergi ke rawa memberi sesajen. Upacara sedekah rowo adalah salah satu perwujudan ungkapan rasa syukur masyarakat terhadap Tuhan melalui sumber daya Rawa yang menghidupi mereka. Upacara Sedekah rowo dimaksudkan sebagai rasa syukur terutama para nelayan atas diberi keselamatan dan penghasilan berupa ikan dan berharap supaya para nelayan ini selalu diberi hasil yang banyak dan selalu diberi keselamatan. Secara lahiriah, Sedekah Rowo memiliki makna adanya silaturahmi antar anggota kelompok tani dan nelayan di Danau Rawa Pening. Sedangkan sedekah rowo makna batiniahnya adalah sebagai ungkapan rasa syukur kepada Allah SWT atas rejeki yang didapat dari Danau Rawa Pening. 


\section{Kesimpulan}

Peran masyarakat Muslim adalah dengan mengembangkan budaya partisipasi aktif, rasa saling percaya, dan toleransi, untuk pelestarian lingkungan. Adapun peran-peran masyarakat tersebut adalah; Menjaga malam secara gentenan dan gentian; tidak menggunakan strum atau racun dalam mendapatkan ikan; mengedepankan kejujuran yang berarti pembagian hasil panen, pembagian dan distribusi pupuk, dan seterusnya; mengutamakan waktu shalat, hari jum'at warga libur, dan kalau sore berangkat setelah maghrib; Resikresik rowo; Belas kasih untuk melakukan tindakan yang bersifat membantu terhadap orang lain. Membantu orang lain diwujudkan dalam bentuk kerja bakti, gotong royong, gugurgunung, sambatan, jagongan dan rewang. Apabila ada tetangga punya hajat seperti supitan (khitan), babaran (melahirkan), mantenan (pesta perkawinan), layat (takziyah) tanpa diundang pun tetangga yang lain bersedia dan siap membantu; merubah konflik menjadi apik; merubah sampah jadi berkah, Eceng Godok jadi souvenir dan furniture, serta sedimentasi Eceng Godok jadi pupuk; melakukan penebaran benih ikan; dan Sedekah Rowo.

Kesadaran dan solidaritas sosial masyarakat Muslim dalam mengembangkan budaya partisipasi aktif, rasa saling percaya, dan toleransi, menjadi penting untuk pelestarian lingkungan rawa. Kecintaan dan kebiasaan untuk memelihara lingkungan hidup dan alam sekitar tentunya akan sejalan dengan tingkat pendidikan dan kematangan budaya, pengalaman dan kedewasaan sebuah masyarakat. Kompleksitas dan multidimensi problema lingkungan yang sedemikian rupa memerlukan horison dan kerangka kerja yang mampu mengakomodasi semua dimesi yang terlibat dalam masalah-masalah lingkungan. Dimensi-dimensi spiritualitas dan rasionalitas serta wawasan kosmik dan humanistik secara bersamaan, merupakan salah satu formula yang menjanjikan untuk membangun sistem ekologi yang bisa membantu mengatasi krisi ekologis dan masalah-masalah lingkungan. Wawallabu a'lamu bishawab. 


\section{Daftar Pustaka}

Abdillah, Mujiono. 2001. Agama Ramah Lingkungan Perspektif Alquran. Jakarta: Paramadina.

Abdullah, M. Amin. 2000. Kata Pengantar, dalam buku Mircea Eliade, dkk. Metodologi Studi Agama. Ahmad Norma Permata (ed). Yogyakarta: Pustaka Pelajar.

Abdullah, M. Amin. 2006. Islamic Studies Di Perguruan Tinggi Pendekatan Integratif-Interkonektif, Yogyakarta: Pustaka Pelajar.

Asy'arie, Musa. 2001. Filsafat Islam Sunnah Nabi Dalam Berpikir. Yogyakarta: Lesfi.

Bakker, Anton dan Ahmad Charris Zubair. 1994. Metoologi Penelitian Filsafat. Yogyakarta: Kanisius.

Balai Pengkajian Teknologi Pertanian (BPTP) Jawa Tengah. 2001. Laporan Penelitian. Ungaran: Pengkajian SUT Ikan, padi, sayuran di Kawasan Rawa Pening.

Cox, James L. 2006. A Guide to the Phenomenology of Religion. Key Figures, Formative Influences and Subsequent Debates. London and New York: Continuum.

Durkheim, Emile, 1912. The Elementary Forms of the Religious Life. English translation by Joseph Swain: 1915. The Free Press, 1965. ISBN 0-02-908010-X, new translation by Karen E. Fields 1995, ISBN 0-02-907937-3

Durkheim, Emile. 1955. Professional Ethics and Civic Morals. English translation by Cornelia Brookfield 1992, ISBN 0-415-06225-X.

Kaelan. 2005. Metode Penelitian Kualitatif Bidang Filsafat. Yogyakarta: Paradigma.

Keraf, A. Sonny. 2002. Etika Biosentrisme Sebuab Revolusi Moral. Jakarta: Kompas, 16 Februari.

Keraf, A. Sonny. 2006. Etika Lingkungan. Jakarta: Penerbit Buku Kompas.

Lee, Antony Ironi Eceng Godok. 24 Mei 2008. www.kompas.com (online), diakses tanggal 8 Juni 2008.

Llewelyn, Othman. 2007. Fiqh al-Biah: Sumbangsih Syariah untuk Konservasi Lingkungan, Paper pada Colloqium on Islamic 
Fiqh On The Environment, 21-22 Juni 2007. Jakarta: UIN Syarif Hidayatullah

Mudofir. 2009. Argumen Konservasi Lingkungan sebagai Tujuan Tertinggi Syari'ah, Disertasi. Jakarta: UIN Syarif Hidayatullah. Muhirdan. 2008. Etika Lingkungan Hidup Dalam Alquran, Tesis. Yogyakarta: UIN Sunan Kalijaga.

Rahmat. 2007. Implementasi Nilai-Nilai Islam Terhadap Pembinaan Kesadaran Lingkungan Hidup Di MAN Daerah Istimewa Yogyakart. Disertasi. Yogyakarta: UIN Sunan Kalijaga

Salganik, M.J. and D.D. Heckathorn. 2004. "Sampling and Estimation in Hidden Populations Using RespondentDriven Sampling". Sociological Methodology 34: 193-239, dalam http://onlinelibrary.wiley.com/doi/10.1111/j.00811750.2004.00152.x/abstract

Spradley, James P. 1980. Participant Observation. USA: Holt, Rinehart and Winston; 1st edition. ISBN: 0030445019.

Wardani, Naniek Sulistya dkk. 2007. Laporan Penelitian Aspek-aspek Sosial Ekonomi Nelayan di Sekitar Rawa Pening, Salatiga: Pusat Studi Rawa Pening Universitas Kristen Satya Wacana. 